\title{
Kebijakan Dana Desa dan Konflik Sosial: Studi Kasus di Sungai Tabuk, Kalimantan Selatan
}

\author{
Adis Imam Munandar1, Muhammad Lutfi Ikhwan² \\ 1Program Studi Kajian Ketahanan Nasional, Sekolah Kajian Stratejik dan Global, Universitas Indonesia. \\ E-mail: adis.imam@ui.ac.id \\ 2Program Studi Kajian Ketahanan Nasional, Sekolah Kajian Stratejik dan Global, Universitas Indonesia. \\ E-mail: lutfiikhwan22@gmail.com
}

\section{ARTICLE INFO}

Keywords: social conflict, stakeholder, village fund

Kata kunci: konflik sosial, pemangku kepentingan, dana desa

How to cite:

Munandar, A. I., \&

Ikhwan, M. L. (2019).

Kebijakan Dana Desa dan Konflik Sosial: Studi Kasus di Sungai Tabuk, Kalimantan Selatan. JAKPP (Jurnal Analisis Kebijakan dan Pelayanan Publik), 5(2), 106-124

\section{ABSTRACT}

Village funds are a government effort to improve welfare and equity, but also trigger social conflict in their use. This study aims to map and mitigate social conflicts in the use of village funds. The research method is descriptive qualitative using primary data and secondary data. The results of the study indicate there are social conflicts both horizontally and vertically and internally-externally at village fund stakeholders. Triggers for social conflict from unpreparedness, suspicion, ignorance, and interests that occur. Efforts to improve the readiness and quality of human resources, socialization and mediation can reduce the potential for social conflict.

\begin{abstract}
Abstrak
Dana desa merupakan upaya pemerintah meningkatkan kesejahteraan dan pemerataan, namun juga memicu konflik sosial pada pengunaannya. Penelitian ini bertujuan memetakan dan memitigasi konflik sosial pada penggunaan dana desa. Metode penelitian dengan deskriptif kualitatif dengan menggunakan data primer dan data sekunder. Hasil penelitian menunjukkan adanya konflik sosial baik horizontal-vertikal maupun internal-eksternal pada stakeholder dana desa. Pemicu konflik sosial dari ketidaksiapan, kecurigaan, ketidakpedulian dan kepentingan yang terjadi. Upaya peningkatan kesiapan dan kualitas SDM, sosialisasi serta mediasi dapat mengurangi potensi konflik sosial.
\end{abstract}

Copyright (C) 2019 JAKPP. All rights reserved.

\section{Pendahuluan}

Desa merupakan kesatuan masyarakat hukum yang memiliki batas-batas wilayah yang berwenang untuk mengatur dan mengurus urusan pemerintah, kepentingan masyarakat setempat berdasarkan prakarsa masyarakat, hak asal usul, dan hak tradisional yang diakui dan dihormati dalam sistem pemerintahan Negara Kesatuan Republik Indonesia (UU No 6 tentang Desa, 2014). Masyarakat di desa pada umumnya saling bergotong royong dan mengenal satu sama lain, dan memiliki tata cara sendiri untuk mengatur kehidupan sosialnya. Desa berada dibawah pemerintahan kabupaten, dan untuk pengelolaannya menggunakan konsep desentralisasi. Desentralisasi adalah penyerahan perencanaan, kewenangan administratif, dan pembuatan keputusan dari 
pemerintah pusat kepada organisasi wilayah, administratif daerah, atau lembaga swadaya masyarakat (Lewis dan Pattinasarany, 2009)

Desa memiliki beberapa istilah, seperti gampong (Aceh), kampung (Sunda), nagari (Padang), wanus (Sulawesi Utara), dan huta (Batak). Desa di Indonesia memiliki ciri-ciri yang hampir sama seperti jumlah penduduk dan luas wilayah desa tidak begitu besar, kegiatan ekonomi mayoritas agraris, dan hubungan antar warga desa masih akrab (Kemendes PDTT, 2016). Desa di Indonesia dibedakan menjadi dua jenis, desa umum dan desa adat (UU No 6 tentang Desa, 2014). Desa Adat adalah kesatuan masyarakat hukum adat yang secara historis memiliki batas wilayah dan identitas budaya yang terbentuk karena dasar tertorial dan memiliki kewenangan untuk mengatur serta mengurus kepentingan masyarakat desa. Desa berdasarkan tingkat perkembangannya dibedakan menjadi tiga jenis, Desa Swasembada, Desa Swakarya, dan Desa Swadaya (Kemendagri, 2016).

Desa di Indonesia saat ini masih mengalami banyak permasalahan, sampai saat ini setidaknya terdapat 2.984 desa di seluruh wilayah Indonesia berkategori desa tertinggal dan desa sangat tertinggal (Kemendes PDTT, 2016). Desa baik yang tertinggal dan sangat tertinggal tentunya terjadi karena masih banyaknya faktor permasalahan yang belum dapat diselesaikan secara tuntas. Desa mengalami ketertinggalan terjadi karena tiga faktor yaitu, Sumber Daya Alam (SDA), Sumber Daya Manusia (SDM), dan Prasarana (Bratakusumah et al, 2006). Sumber Daya Alam (SDA) menjadi faktor pertama karena tidak semua daerah/desa memiliki sumber daya alam, baik yang berlimpah atau hanya sekedar ada, ketika sumber daya alam disuatu desa memang sama sekali tidak ada maka desa tersebut akan sangat tergantung dengan desa/daerah lain dan masyarakat cenderung akan mencari pekerjaan karena terbatasnya lapangan pekerjaan (Bratakusumah et al, 2006). Faktor kedua adalah Sumber Daya Manusia (SDM), sangat berkaitan erat dengan sumber daya manusia karena ketika desa memiliki sumber daya alam tapi tidak didukung oleh kemampuan masyarakatnya untuk mengelola maka sumber daya alam yang dimiliki tidak bisa dimanfaatkan untuk meningkatkan perekonomian desa. Faktor ketiga adalah prasana, dimana masih kurangnya prasarana untuk menopang kegiatan perekonomian masyarakat desa.

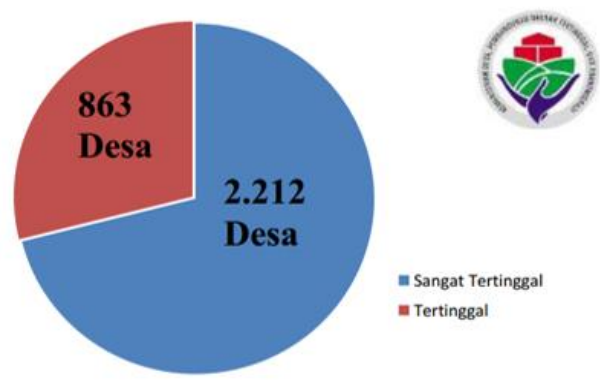

Gambar 1. Jumlah Desa Tertinggal dan Sangat Tertinggal di Indonesia Sumber: Kemendes PDTT, 2016

Desentralisasi desa-desa di wilayah Indonesia akan berjalan dengan baik jika daerah dapat menjalankannya dengan tanggungjawab, proporsional dan berkeadilan, dengan itu maka hasil dari adanya desentralisasi dapat dicapai dengan maksimal (Kemendagri, 2016). Indonesia saat ini memiliki sekitar 74.957 desa yang tersebar diseluruh wilayah 
(Kemendes PDTT, 2016). Pemerintahan Desa merupakan pemerintahan yang bersentuhan langsung dengan masyarakat, karena itu fokus pemerintah pusat yaitu pembangunan dilakukan dari pedesaan. Otonomi daerah bertujuan untuk memberdayakan daerah dengan meningkatkan kesejahteraan, perlindungan, pelayanan dan peran masyarakat (Sinamo, 2014).

Adanya dana desa untuk membantu membangun desa. Dana Desa dalam penggunaannya diserahkan sesuai dengan kebutuhan oleh masing-masing desa tetapi tetap harus mengacu kepada peraturan yang sudah dibuat oleh pemerintah. Berdasarkan Permendes Nomor 19 tahun 2017 prioritas penggunaan Dana Desa adalah untuk pembangunan infrastruktur desa dan pemberdayaan masyarakat desa. Pemerintah Desa dalam penggunaan Dana Desa ini juga harus mengedepankan prinsip keadilan, di mana mengutamakan hal dan kepentingan seluruh warga Desa tanpa membeda-bedakan (Kementerian Keuangan, 2017).

Dana Desa dalam penggunaannya diserahkan sesuai dengan kebutuhan oleh masing-masing desa tetapi tetap harus mengacu kepada peraturan yang sudah dibuat oleh pemerintah. Berdasarkan Permendes Nomor 19 tahun 2017 prioritas penggunaan Dana Desa adalah untuk pembangunan infrastruktur desa dan pemberdayaan masyarakat desa. Pemerintah Desa dalam penggunaan Dana Desa ini juga harus mengedepankan prinsip keadilan, di mana mengutamakan hal dan kepentingan seluruh warga Desa tanpa membeda-bedakan (Kementerian Keuangan, 2017).

Dana desa menimbulkan konflik baru. Satuan Tugas (Satgas) Dana Desa terhitung sampai September 2017 sudah menerima sekitar 10.000 laporan yang datang dari masyarakat tentang konflik dan penyalahgunaan dana desa dari seluruh wilayah Indonesia (Koran Sindo, 2017). Pemerintah harus memberikan perhatian khusus terhadap risiko konflik antarwarga desa, terutama pada saat pemilihan kepala desa (Koran Sindo, 2017). Rawan untuk terjadi konflik karena kepala desa menjadi pengguna anggaran dana desa sehingga pemilihan kepala desa menghadirkan banyak calon beserta basis pendukung yang tidak sedikit. Salah satu contoh terjadi konflik karena adanya Dana Desa terjadi di Desa Jatimulyo Kecamatan Dlingo Kabupaten Bantul terjadi pada saat pemilihan langsung yang dilakukan di desa tersebut (Puspaningrum, 2016).

Dana desa juga memicu adanya korupsi yang terjadi, Korupsi yang terjadi di desa terutama yang berkaitan dengan anggaran desa menjadi salah satu permasalahan yang mendasar (ICW, 2018). Korupsi menjadi permasalahan di desa saat ini karena pengelolaan anggaran yang besar tapi dalam pelaksanaannya tidak didasari dengan transparansi serta akuntabilitas dalam tata kelola politik, keuangan desa dan pembangunan (ICW, 2018). Data ICW (2018) menunjukkan kasus korupsi di desa meningkat dan perangkat desa yang tersangkut korupsi tren naik. Hal ini menunjukkan konflik yang terjadi di desa. 


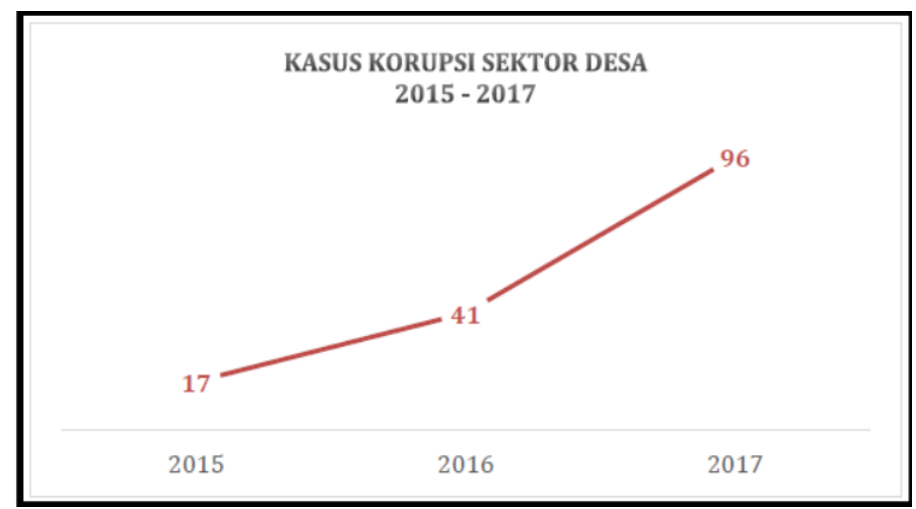

Gambar 2. Kasus korupsi sektor Desa

Sumber: Indonesia Corruption Watch (2018)

ICW (2018) menyatakan bahwa aktor dominan dalam kasus merupakan Kepala Desa, dimana jumlahnya sekitar 112 orang. Pelaku korupsi juga ada diluar Kepala Desa, pelaku lain adalah 32 perangkat desa dan 3 orang merupakan keluarga Kepala Desa terlihat pada Gambar 3. Program Dana Desa yang bersumber dari APBN ini tidak pasti selalu membuat desa menjadi lebih baik dari sebelumnya. Adanya dana desa tergantung pada Kepala Desa beserta aparaturnya, maksudnya di sini adalah kesiapan dari sumber daya manusia yang dimiliki desa.

Daaraba (2017) menyatakan bahwa Musrenbang Desa saat ini hanya sekadar formalitas karena Musrenbang tidak melibatkan masyarakat. Semua usulan hanya berdasarkan pada keputusan Kepala Desa ditambah pengelolaan juga hanya dilakukan oleh Kepala Desa. Kasus ini memperlihatkan bahwa dalam pengelolaannya sama sekali tidak melibatkan masyarakat desa tersebut, bahkan tidak mengikutsertakan Badan Permusyawaratan Desa (BPD) untuk memutuskan secara bersama apa prioritas yang dibutuhkan oleh masyarakat.

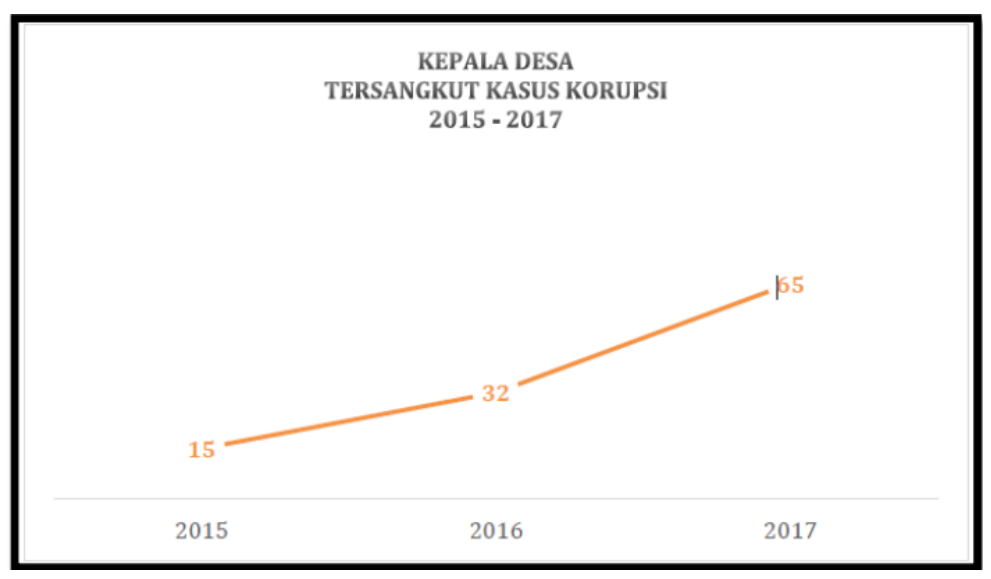

Gambar 3. Kasus korupsi sektor Desa

Sumber: Indonesia Corruption Watch (2018)

Syamsi (2009) mengatakan pemerintah harus memberikan perhatian khusus terhadap risiko konflik antarwarga desa, terutama pada saat pemilihan kepala desa. Rawan untuk terjadi konflik karena kepala desa menjadi pengguna anggaran dana desa sehingga pemilihan kepala desa menghadirkan banyak calon beserta basis pendukung yang tidak sedikit. Korupsi merupakan salah satu permasalahan selain terjadinya konflik 
karena adanya Dana Desa. Desa Jatimulyo Kecamatan Dlingo Kabupaten Bantul terjadi konflik antar pendukung calon kepala desa pada saat pemilihan langsung yang dilakukan di desa tersebut (Puspaningrum, 2016). Korupsi yang terjadi di desa terutama yang berkaitan dengan anggaran desa menjadi salah satu permasalahan yang mendasar (ICW, 2018). Korupsi menjadi permasalahan di desa saat ini karena pengelolaan anggaran yang besar tapi dalam pelaksanaannya tidak didasari dengan transparansi serta akuntabilitas dalam tata kelola politik, keuangan desa dan pembangunan (ICW, 2018).

Penelitian sebelumnya diantaranya membahas tentang Dana Desa dan Permasalahan Hukum yang ditimbulkan (Pahlevi, 2015), Konflik Peran Perangkat Desa terhadap Pengelolaan Keuangan Desa (Wulandari et al. 2017), Partisipasi Masyarakat dalam Pengawasan Program Dana Desa (Bahtiar, 2017), Fenomena Pengawasan Publik terhadap Dana Desa (Wibisono dan Purnomo, 2017), dan pengelolaan dana desa dengan peraturan perudang-undangan (Noverman 2018). Penelitian sebelumnya banyak membahas tentang pengawasan yang dilakukan oleh masyarakat dalam pelaksanaan Dana Desa, dan penelitian untuk konflik yang ditimbulkan karena adanya program tersebut masih sedikit. Penelitian ini juga memiliki perbedaan karena lokasi penelitian yang diambil memiliki karakteristik tersendiri, lokasi penelitian berada jauh dari pusat kota dari Kota Banjarmasin. Pemilihan lokasi penelitian di desa dikarenakan memiliki tingkat kemiskinan lebih tinggi dibandingkan kota (BPS 2018). Pemilihan wilayah Banjar di Kalimatan Selatan dikarenakan memiliki jumlah penduduk miskin yang tinggi dan jumlah desa yang terbanyak di Kalimantan Selatan (BPS 2018). Pada kecamatan Sungai Tabuk dan desa-desanya merupakan perpaduan dari masyarakat perdesaan dan masyarakat pinggiran perkotaan. Berdasarkan latarbelakang tersebut maka pertanyaan penelitian bagaimana peta aktor dari potensi konflik sosial di Wilayah Sungai tabuk, Banjar, Kalimatan Selatan. Pada penelitian ini bertujuan untuk memetakan konflik sosial yang dapat terjadi akibat adanya dana desa dan upaya memitigasi konflik yang terjadi.

\section{Kajian Literatur}

Permasalahan konflik sosial cukup rumit untuk dibahas karena berkaitan dengan semua aspek kehidupan manusia. Konflik adalah sebuah perjuangan antar individu atau kelompok untuk memenangkan suatu tujuan yang diinginkan. Konflik dapat diartikan bahwa baik individu atau kelompok mempunyai kepentingan yang dicoba untuk dicapai dengan cara persaingan dan perjuangan. Perebutan kepentingan dapat terjadi konflik antar individu atau kelompok karena mereka mengambil langkah-langkah yang dinilai melanggar hukum (Reyes-Garcia et al., 2012). Konflik merupakan pertentangan individu dengan individu, kelompok dengan kelompok, atau individu dengan kelompok (Francis \& Tamoya, 2013). Konflik yang ada di masyarakat merupakan sesuatu yang tidak bisa untuk dihindari, maka yang perlu untuk diketahui adalah dalam bentuk apakah konflik tersebut terjadi, bertentangan tajam atau sekadar perbedaan pandangan. Tingkat kekerasan konflik juga perlu diperhatikan karena menyangkut sarana yang digunakan, mulai dari negosiasi hingga saling menyerang secara fisik (Sumartias \& Rahmat, 2013).

Menurut Fisher et al. (2000) konflik sosial secara teoritis dapat dibagi ke dalam dua bentuk yaitu, konflik vertical dan konflik horizontal. Konflik vertikal merupakan konflik 
yang terjadi antara elit dengan massa atau dalam hal ini adalah masyarakat, sedangkan konflik horizontal yaitu konflik yang terjadi di antara massa (masyarakat) itu sendiri (Roger, 2012). Potensi konflik vertikal dan horizontal dapat terjadi ketika, (1) saluran dialog untuk mengungkapkan pendapat tidak memadai; (2) Aspirasi ketidaksepakatan atau keluhan yang ada tidak didengar; (3) Ketakutan masyarakat yang luas tentang ketidakadilan (Fisher et al. 2000).

Konflik merupakan gejala sosial yang akan selalu ada karena adanya hubungan sosial yang terjadi baik di tingkat individu atau di tingkat kelompok. Menurut Coser (tahun) itu terjadi karena keinginan individu maupun kelompok untuk meningkatkan kesejahteraan, kekuasaan, prestise, atau dukungan sosial (Francis dan Tamoya, 2013). Hubungan sosial yang terjadi di masyarakat baik di tingkat individu maupun kelompok terdapat persamaan dan perbedaan di antara mereka sendiri. Persamaan dan perbedaan tersebut menyangkut jenis kelamin, tingkat pendidikan, pekerjaan, latar belakang budaya, cita-cita, dan kepentingan. Perbedaan dan persamaan tidak mungkin dapat bisa untuk dihindari, jadi ketika saling bertemu dan bergesekan berpotensi menimbulkan konflik. Berdasarkan kesamaan keinginan atas sesuatu, sementara sesuatu tersebut merupakan sumber daya yang terbatas, maka akan menimbulkan kompetisi dan perebutan keinginan masing-masing. Konflik terjadi di tengah-tengah masyarakat karena ketidaksetaraan yang terjadi dan tidak bisa dihindari antara "yang berpunya" dan "yang tidak berpunya" (Barret \&Setiawan, 2016).

Akar dari munculnya konflik adalah adanya hubungan sosial, ekonomi, dan politik yang mana akarnya karena perebutan sumber-sumber kepemilikan, status sosial, dan kekuasaan, yang jumlah ketersediannya terbatas (Bakri, 2015). Terjadi ketidakmerataan pembagian aset sosial di tengah masyarakat. Individu atau kelompok yang sudah mendapatkan status sosial atau kekuasaan disebut sebagai staus quo sedangkan pihak yang berusaha mendapatkannya disebut sebaga status need.

Menurut Sherif et al. (1961) Realistic Conflict Theory, merupakan teori ekonomi untuk melihat perilaku antarkelompok. Perilaku antarkelompok adalah suatu hubungan antara dua atau lebih kelompok dan masing-masing anggota kelompok tersebut. Teori ini memiliki beberapa pandangan, seperti: (1) bahwa konflik itu pada dasarnya buruk; (2) manusia bersifat egois untuk memaksimalkan keuntungan dirinya; (3) konflik terjadi ketika satu pihak memaksimalkan keuntungan dirinya dan bersentuhan dengan kepentingan pihak lain (Reyes-Garcia et al., 2012). Teori realistic conflict theory dapat menjelaskan konflik sosial di tengah-tengah masyarakat. Manusia bersifat egois karena dengan menjadi kepala desa atau bagian dari perangkatnya maka dapat memaksimalkan keuntungan yang dimilikinya, karena secara hukum mereka merupakan pihak yang legal dalam mengatur penggunaannya. Keuntungan tersebut akhirnya bergesekan dengan kepentingan pihak-pihak lain yang seharusnya juga merasakan penggunaan Dana Desa dengan dasar keadilan.

Penelitian mengenai konflik dilakukan oleh peneliti terdahulu. Mann \& Jeanneux (2009) mengkaji konflik lahan di pedesaan, Czalika \& Kritztina (2009) mengkaji konflik sipil pada migrasi desa di Aceh, Syamsi (2009) mengkaji konflik sosial masyarakat Condongcatur, Yogyakarta pada kelas sosial yang terjadi, Muda (2013) mengkaji konflik horizotal anta suku terkait kelas sosial, Susan (2013) mengkaji konflik sosial pada lahan di 
Sumatera Utara dan Yamazaki et al. (2015) mengkaji konflik di desa pesisiran. Berbagai penelitian tersebut lebih ke konflik di desa mengenai lahan atau konflik kelas sosial yang terjadi. Pada kajian ini berfokus pada konflik sosial dengan adanya dana desa.

Penelitian mengenai dana desa juga telah dilakukan peneliti terdahulu. Pahlevi (2015) mengenai penyaluran dan masalah hukum yang terjadi dana desa, Meutia \& Liliana (2017) mengenai pengelolaan keuangan dana desa, Shohibuddin (2016) mengenai otonomi dana desa, Wulandari et al. (2017) mengenai konflik peran pengelolaan dana desa, Bahtiar (2017) mengenai pengawasan program alokasi dana desa, Wibisono \& Purnomo (2017) mengenai pengawasan publik dana desa, Fahri (2017) mengenai manajemen keuangan desa, serta Noverman (2018) mengenai kesesuian undang-undang dan pengelolaan dana desa. Berbagai kajian tersebut hanya berfokus pada aspek hukum, manajemen dan pengelolaan. Namun kajian mengenai dana desa dan konflik sosial yang terjadi masih cukup sedikit terutama di desa.

\section{Metode Penelitian}

Konflik sosial merupakan terjadinya interaksi sosial antar aktor yang dapat dijelaskan dengan baik dengan menggunalan metode kualitatif deskriptif. Penelitian kualitatif deskriptif bertujuan untuk menjelaskan secara lengkap dan apa adanya tentang fenomena sosial yang terjadi (Creswell, 2007). Penelitian kualitatif deksriptif berfokus pada hubungan sosial, fenomena sosial, dan juga hal lain yang berkaitan dengan ilmuilmu sosial yang sesuai dengan dengan tujuan penelitian. Data yang muncul dalam penelitian ini yaitu dalam bentuk kata-kata.

Sumber data primer, data diperoleh secara langsung dengan melakukan teknik wawancara mendalam kepada narasumber-narasumber yang berkaitan dengan konflik yang disebabkan oleh dana desa dan mitigasi konflik tersebut. Penelitian ini juga akan menggunakan wawancara terstruktur dalam tujuan untuk pemenuhan kebutuhan data primer dan mendukung data yang didapatkan dalam wawancara mendalam yang dilakukan dengan narasumber-narasumber terkait dengan tujuan penelitian. Informan yang digunakan adalah Kepala Desa (2 orang), Ketua RT (1 orang), Pendamping Desa untuk Dana Desa (1 orang), Badan Permusyarakatan Desa (1 orang), Tenaga Ahli untuk Dana Desa (1 orang), Sekretaris Desa (1 orang), Warga desa (2 orang). Sejumlah 9 informan tersebut mewakili masing-masing aktor yang terlibat dalam konflik sosial dana desa. Ruang lingkup pada kajian konflik sosial meliputi konflik sosial antar aktor atau individu yang mendapatkan dana desa

Sumber data sekunder akan didapatkan dari penelitian penelitian yang dilakukan sebelumnya (terdahulu), dimana masih memiliki keterkaitan dengan konflik yang terjadi di desa karena adanya program Dana Desa dan upaya untuk mitigasi konflik tersebut agar dampaknya ketika terjadi dapat diminimalisir. Data-data (dokumen) dalam bentuk laporan yang memiliki relevansi dengan masalah yang dibahas dalam penelitian ini.

Lokasi penelitian ini akan berfokus di pedesaan wilayah Kecamatan Sungai Tabuk yang terdiri dari 20 desa, Kabupaten Banjar, Kalimantan Selatan. Pemilihan lokasi mengacu desa yang terbanyak di Kalimantan selatan dan memiliki tingkat kemiskinan yang cukup tinggi dibandingkan dengan wilayah lain di Kalimantan. Berdasarkan 
observasi dan wawancara awal yang dilakukan dengan Stakeholders terkait maka lokasi penelitian akan difokuskan di pedesaan wilayah tersebut, dimana kecamatan tersebut terdiri dari 20 Desa.

\section{Hasil dan Pembahasan}

\section{Konflik Sosial Pada Penggunaan Dana Desa di Sungai Tabuk}

Dana Desa adalah dana yang bersumber dari Anggaran Pendapat dan Belanja Negara dan dana tersebut disalurkan atau ditransfer melalui Anggaran Pendapatan dan Belanja Daerah Kabupaten/Kota (Kemenkeu 2017). Dana Desa diperuntukan untuk membiayai pembangunan dan pemberdayaan masyarakat desa, harapannya yaitu untuk meningkatkan kapasitas dari Pemerintah Desa, infrastruktur perdesaan dan tentunya meningkatkan kualitas Sumber Daya Manusia (SDM) yang tentunya sesuai dengan indikator dari desa mandiri (Kemendes PDTT, 2016). Dana Desa diharapkan dapat menjadi solusi yang tepat untuk mengatasi permasalahan kemiskinan, ketertinggalan, dan kesenjagangan yang terjadi di perdesaan di wilayah Indonesia

Dana Desa merupakan kebijakan yang dapat menyentuh langsung ke pembangunan di wilayah perdesaan, dan tentunya dengan nominal dana yang besar (Kemedagri, 2016). Dana desa dari awal hingga akhir banyak yang terlibat seperti Kepolisian, Badan Pemeriksa Keuangan (BPK), Kejaksaan, Inspektorat, dan lembaga pemeriksa lainnya. Pemeriksaan yang dilakukan disamaratakan dengan pemeriksaan yang dilakukan kepada instansi-instansi pemerintah daerah, padahal di masyarakat tingkat desa belum siap menerima pemeriksaan dengan standar tinggi. Sesuai dengan informan kepala desa "pemahaman dalam penggunaannya pak masih kurang, masih tidak terlalu paham peruntukannya, apalagi ditahun awal tahun 2015, masih susah waktu itu untuk pelaporannya".

Hasil kutipan wawancara denagn informan tenaga ahli desa:

"perangkat diminta untuk membuat $R A B$, kita kasih contoh tapi kebanyakan masih belum sesuai, memang tidak bias disamakan laporan yang mereka buat dengan laporan kedinasan, kadang saya kasihan, memang harusnya tidak disamakan. Pemerintah desa sering tertuduh oleh warganya sendiri disini, dianggap tidak transparan"

Sumber Daya Manusia di Pemerintah Desa, baik Kepala Desa, Perangkat Desa, bahkan Pendamping Lokal Desa (PLD) hanya bisa membuat gambar dan Rencana Aanggaran Biaya (RAB) sederhana. Potensi konflik disini adalah antara unsur Pemerintah Desa dan PLD yang saling menyalahkan satu sama lain, terjadi karena faktor ketidaksiapan. Didukung hasil dari pernyataan informan tenaga ahli dana desa sebagai berikut

"Dana desa disisi yang menimbulkan permasalahan karena perangkat desa tidak siap untuk menerima dan menggunakan dana tersebut, tidak siap dengan adanya dana desa, ketidaksiapan tesrsebut membuat terjadinya kasus kepala desa yang tersangkut kasus hokum seperti penyelewangan dana desa"....informan tenaga ahli dana desa. 
Tabel 1 dibawah menunjukkan ketidaksiapan dan potensi konflik yang terjadi.

Tabel 1 Ketidaksiapan Pemerintah Desa, Masyarakat Desa, dan Pendamping Lokal Desa (PLD) di Sungai Tabuk

\begin{tabular}{|c|c|c|}
\hline Unsur & aksiapan & Potensi Konflik \\
\hline $\begin{array}{l}\text { Pemerintah } \\
\text { Desa (Kepala } \\
\text { Desa dan } \\
\text { Perangkat } \\
\text { Desa) }\end{array}$ & $\begin{array}{l}\text { Pendidikan masih rendah Kepala } \\
\text { Desa dan Perangkat Desa, Dana } \\
\text { Desa menuntut untuk siap } \\
\text { membuat laporan perencanaan } \\
\text { dan laporan } \\
\text { pertanggungjawaban. Konsep dan } \\
\text { arah pembangunan menjadi } \\
\text { kurang matang }\end{array}$ & $\begin{array}{l}\text { Ketidaksiapan Pemerintah } \\
\text { Desa dalam hal ini kepala } \\
\text { Desa dan Perangkat Desa } \\
\text { membuat potensi konflik } \\
\text { terjadi antara unsur } \\
\text { Pemerintah Desa sendiri dan } \\
\text { potensi konflik dengan } \\
\text { masyarakat desa. }\end{array}$ \\
\hline $\begin{array}{l}\text { Masyar } \\
\text { Desa }\end{array}$ & $\begin{array}{l}\text { Tidak ada edukasi dan } \\
\text { pemahaman yang diberikan } \\
\text { Pemerintah Desa kepada } \\
\text { masyarakatnya dan membiaskan } \\
\text { masyarakat untuk sepakat dalam } \\
\text { setiap pembahasan dengan } \\
\text { memberikan honor ketika rapat }\end{array}$ & $\begin{array}{lr}\text { Potensi konflik } & \text { karena } \\
\text { ketidaksiapan ini terjadi } \\
\text { karena ketika honor tidak } \\
\text { lagi diberikan } r \text { kepada } \\
\text { masyarakat desa } r \text { maka } \\
\text { potensi konflik akan muncul } \\
\text { antara masyarakat dengan } \\
\text { Pemerintah Desa }\end{array}$ \\
\hline $\begin{array}{l}\text { Lokal Desa } \\
\text { (PLD) dan } \\
\text { Pendamping } \\
\text { Desa (PD, } \\
\text { Pendamping } \\
\text { ditingkat } \\
\text { Kecamatan) }\end{array}$ & $\begin{array}{l}\text { Pendamping Lokal Desa (PLD) } \\
\text { merupakan masyarakat lokal } \\
\text { dalam usia produktif tapi juga } \\
\text { masih belum siap dalam } \\
\text { membantu Pemerintah Desa } \\
\text { dalam penggunaan Dana Desa }\end{array}$ & $\begin{array}{l}\text { Potensi konflik terjadi karena } \\
\text { dilapangan pada akhirnya } \\
\text { membuat Pendamping Desa } \\
\text { (PD) harus turun } \\
\text { menyelesaikan tugas yang } \\
\text { seharusnya dikerjakan oleh } \\
\text { Pendamping Lokal Desa } \\
\text { (PLD) }\end{array}$ \\
\hline $\begin{array}{l}\text { Kepala Desa, } \\
\text { Perangkat } \\
\text { Desa } \\
\text { (Sekretaris } \\
\text { Desa } \\
\text { dan } \\
\text { Bendahara } \\
\text { Desa) dan } \\
\text { Pendamning }\end{array}$ & $\begin{array}{l}\text { Ketidaksiapan } \\
\text { pemeriksaan oleh } \\
\text { Kejaksaan, Bepolisian } \\
\text { Keuangan (BPK), dan instansi } \\
\text { lainnya }\end{array}$ & $\begin{array}{lr}\text { Potensi konflik terjadi antar } \\
\text { unsur tersebut karena akan } \\
\text { cenderung } \\
\text { menyalahkan } \\
\text { pemeriksaan } \\
\text { menghasilkan temuan yang } \\
\text { mengindikasikan } \\
\text { kesalahan yang dilakukan } \\
\text { dalam penggunaan Dana } \\
\text { Desa }\end{array}$ \\
\hline
\end{tabular}

Sumber: Wawancara (2018)

Pemicu konflik sosial akibat dari Dana Desa karena ketidaksiapan dari Sumber Daya Manusia (SDM) baik dari Pemerintah Desa maupun masyarakat desa itu sendiri. Ketidaksiapan yang melahirkan kecurigaan dan ketidakpedulian ini, didasari oleh kepentingan yang negatif oleh aktor atau unsur yang terlibat dalam penggunaan Dana 
Desa dilapangan. Didukung oleh pernyataan informan pendamping dana desa sebagai berikut:

“... Pemerintah Desa sering tertuduh oleh warganya sendiri disini, dianggap tidak transparan. Padahal ada juga masyarakat yang tidak peduli, tidak peduli dengan adanua dana desa, ya akhirnya tidak trasnparan pemerintah desanya, rawan masalah hokum akhirnya pak"

Kepentingan yang negatif disini adalah untuk dapat menggunakan dana desa dan memaksimalkan agar dapat menguntungkan aktor tersebut secara pribadi atau memberikan keuntungan kepada kelompoknya. Kepentingan yang negatif ini lahir karena ketidaksiapan Sumber Daya Manusia (SDM) untuk menggunakan Dana Desa sesuai dengan tujuan dan sasaran yang sudah ditetapkan oleh pemerintah. Dampaknya pada akhirnya melahirkan konflik sosial karena untuk memperebutkan keuntungan yang didapatkan dari adanya Dana Desa. Didukung oleh pernyataan informan badan permusyawaratan desa sebagai berikut

"Contohnya seperti konflik yang dipicu untuk mengganti kepala desa dan perangkat desa lainnya, pergantiang dilakukan disini agar memberikan keuntungan kepada mereka, kasus seperti ini pernah terjadi. Pemilihan umum kepla desa merupakan contoh paling nyata"

Aktor-aktor memungkinkan terjadi potensi konflik dengan pihak lain dengan adanya kepentingan. Pada tabel 2 dibawah dipetakan aktor dan potensi konflik sosial yang terjadi di Sungai Tabuk.

Tabel 2. Aktor dalam Konflik Sosial Dana Desa di Desa-desa di Wilayah Kecamatan Sungai Tabuk Kabupaten Banjar

\begin{tabular}{|l|l|}
\hline \multicolumn{1}{|c|}{ Aktor } & \multicolumn{1}{c|}{ Potensi Konflik } \\
\hline Kepala Desa & $\begin{array}{l}\text { Pengguna sah Dana Desa, pimpinan utama Pemerintahan } \\
\text { Desa yang dituntut menggunakan Dana Desa berlandaskan } \\
\text { asas keadilan. Kepala Desa menjadi jabatan yang prestige } \\
\text { karena pengguna utama Dana Desa dan disisi lain } \\
\text { merupakan aktor utama dalam konflik sosial yang terjadi di } \\
\text { wilayah Kecamatan Sungai Tabuk }\end{array}$ \\
\hline $\begin{array}{l}\text { Perangkat Desa } \\
\text { - Sekretaris Desa } \\
\text { - Peranghara }\end{array}$ & $\begin{array}{l}\text { Perangkat Desa merupakan bagian dari Pemerintahan Desa } \\
\text { yang memiliki fungsi untuk membantu Kepala Desa. } \\
\text { Dipilih Kepala Desa biasanya karena faktor kedekatan } \\
\text { walaupun saat ini sudah mulai diatur bahwa posisi tersebut } \\
\text { pemilihannya harus dibentuk tim indipenden terlebih } \\
\text { dahulu. Perangkat desa yang tidak sejalan dengan Kepala } \\
\text { Desa akan berpotensi menimbulkan konflik sosial di } \\
\text { internal Pemerintah Desa itu sendiri, dalam kasus ini di } \\
\text { wilayah Kecamatan Sungai Tabuk }\end{array}$ \\
\hline $\begin{array}{l}\text { Badan } \\
\text { Permusyawaratan } \\
\text { Desa (BPD) } \\
\text { - Ketua BPD }\end{array}$ & $\begin{array}{l}\text { Bnggota BPD } \\
\text { fungsinya yaitu sebagai badan pengawas Pemerintah Desa } \\
\text { ketika menjalankan pemerintahan dan melakukan kegiatan. } \\
\text { BPD juga sebagai penyalur aspirasi utama dari masyarkat } \\
\text { ke Pemerintah Desa atau sebaliknya. Berpotensi konflik, }\end{array}$ \\
\hline
\end{tabular}




\begin{tabular}{|c|c|}
\hline & $\begin{array}{l}\text { bahkan konflik terjadi karena BPD biasanya diisi oleh lawan } \\
\text { politik Kepala Desa, lawan politik disini bisa menjadi ketua } \\
\text { atau anggota dari BPD, kasus seperti ini terjadi di wilayah } \\
\text { Kecamatan Sungai Tabuk. }\end{array}$ \\
\hline $\begin{array}{l}\text { Pendamping Desa } \\
(\text { PD) } \\
\text { Kecamatan }\end{array}$ & $\begin{array}{l}\text { Dihadirkan oleh pemerintah sebagai fasilitator dalam } \\
\text { mengembangkan kapasitas perangkat desa, memfasilitasi } \\
\text { musyarawarah dan rapat-rapat, memperkuat organisasi di } \\
\text { desa, memberikan pengawalan kepada Dana Desa dengan } \\
\text { turut serta memberdayakan desa, dan ditambah dengan } \\
\text { membentuk serta melahirkan kader-kader pembangunan di } \\
\text { desa. Bertugas di tingkat kecamatan dan juga sebagai } \\
\text { kooridnator Pendamping Lokal Desa (PLD). Pendamping } \\
\text { Desa (PD) ditingkat kecamatan terbagi menjadi dua PD } \\
\text { Infrastruktur dan PD Pemberdayaan }\end{array}$ \\
\hline $\begin{array}{l}\text { Pendamping Lokal } \\
\text { Desa (PLD) }\end{array}$ & $\begin{array}{l}\text { Secara umum memiliki fungsi yang sama dengan PD tapi } \\
\text { dengan ruang lingkup yang lebih kecil. PLD bersentuhan } \\
\text { langsung dengan Pemerintah Desa khususnya Kepala Desa } \\
\text { dan merupakan warga lokal di wilayah Kecamatan Sungai } \\
\text { Tabuk. Biasanya memiliki keterkaitan dengan Pemerintah } \\
\text { Desa dan memiliki kedekatan dengan perangkat desa. }\end{array}$ \\
\hline $\begin{array}{l}\text { Masyarakat Desa } \\
\text { - Tokoh Masyarakat } \\
\text { - Ketua RT } \\
\text { - Warga Desa }\end{array}$ & $\begin{array}{l}\text { Masyarakat disini merupakan masyarakat desa secara luas } \\
\text { dimana terdiri dari tokoh masyarakat, ketua RT, dan warga } \\
\text { desa pada umumnya. Potensi konflik disini kebanyakan } \\
\text { karena masalah ketidakadilan yang dirasakan, } \\
\text { ketidakpuasan dengan kinerja oleh Pemerintah Desa dan } \\
\text { pada akhirnya berdampak menimbulkan konflik sosial di } \\
\text { wilayah Kecamatan Sungai Tabuk }\end{array}$ \\
\hline Aktor Kepentingan & $\begin{array}{l}\text { Aktor kepentingan disini terdiri dari beberapa aktor, dari } \\
\text { oknum partai politik dan LSM/Ormas ditingkat Desa. } \\
\text { Aktor kepentingan disini memiliki kepentingan sendiri } \\
\text { dalam Dana desa. }\end{array}$ \\
\hline
\end{tabular}

Sumber: Wawancara (2018)

\section{Peta Konflik Sosial di Wilayah Sungai Tabuk}

Dana Desa langsung dikelola oleh Pemerintah Desa dari proses perencanaan, penggunaan, sampai dalam tahap pertanggungjawaban. Konflik sosial Dana Desa di Kecamatan Sungai Tabuk diwilayah Kabupaten Banjar ini dilihat dari teori konflik maka konflik yang terjadi ini karena ada perjuangan individu ataupun kelompok dalam memperjuangkan kepentingannya, dalam hal ini kepentingannya adalah untuk mendapatkan keuntungan dari Dana Desa. Konflik sosial yang terjadi di desa ini meliputi banyak pihak atau aktor yang terlibat dalam konflik sosial tersebut. Pemilihan umum Kepala Desa saat ini juga menjadi lebih rawan konflik, atau berpotensi menimbulkan konflik sosial (Sukardi, 2016).

Potensi konflik sosial dan konflik yang sudah terjadi di wilayah Kecamatan Sungai Tabuk ini memiliki bentuk konflik vertical dan konflik horizontal. Konflik vertikal 
merupakan konflik yang terjadi antara elit dengan massa atau dalam hal ini adalah masyarakat, sedangkan konflik yang memiliki bentuk horizontal merupakan konflik yang terjadi diantara masyarakat itu sendiri (Roger, 2012). Berdasarkan konsep dari bentukbentuk konflik sosial maka konflik Dana Desa yang terjadi di desa-desa diwilayah Kecamatan Sungai Tabuk ini terjadi dalam dua bentuk, baik konflik vertikal maupun konflik horizontal. Konflik yang terjadi diwilayah Kecamatan Sungai Tabuk merupakan konflik yang lengkap terlihat pada gambar dibawah ini.

Definisi internal merupakan interaksi sosial di aktor-aktor eksekutif di pemerintah desa seperti kepala desa, sekretaris desa, bendahara desa dan perangkat lain. Terjadinya konflik sosial dana desa juga disebabkan kepala desa yang diplih oleh warga, namun perangkat desa merupakan pegawai negeri sipil yang diangkat oleh pemerintah. Sebaliknya definisi eksternal adalah diluar dari aktor eksekutif di pemerintah desa, diantaranya BPD, pendamping desa, masyarakat desa, pedamping local dan lain-lain. Sedangkan konflik vertikal dan horizontal berdasarkan hirarki struktur jabatan pemerintah. Secara garis besar peta aktor terlihat pada Gambar 4.

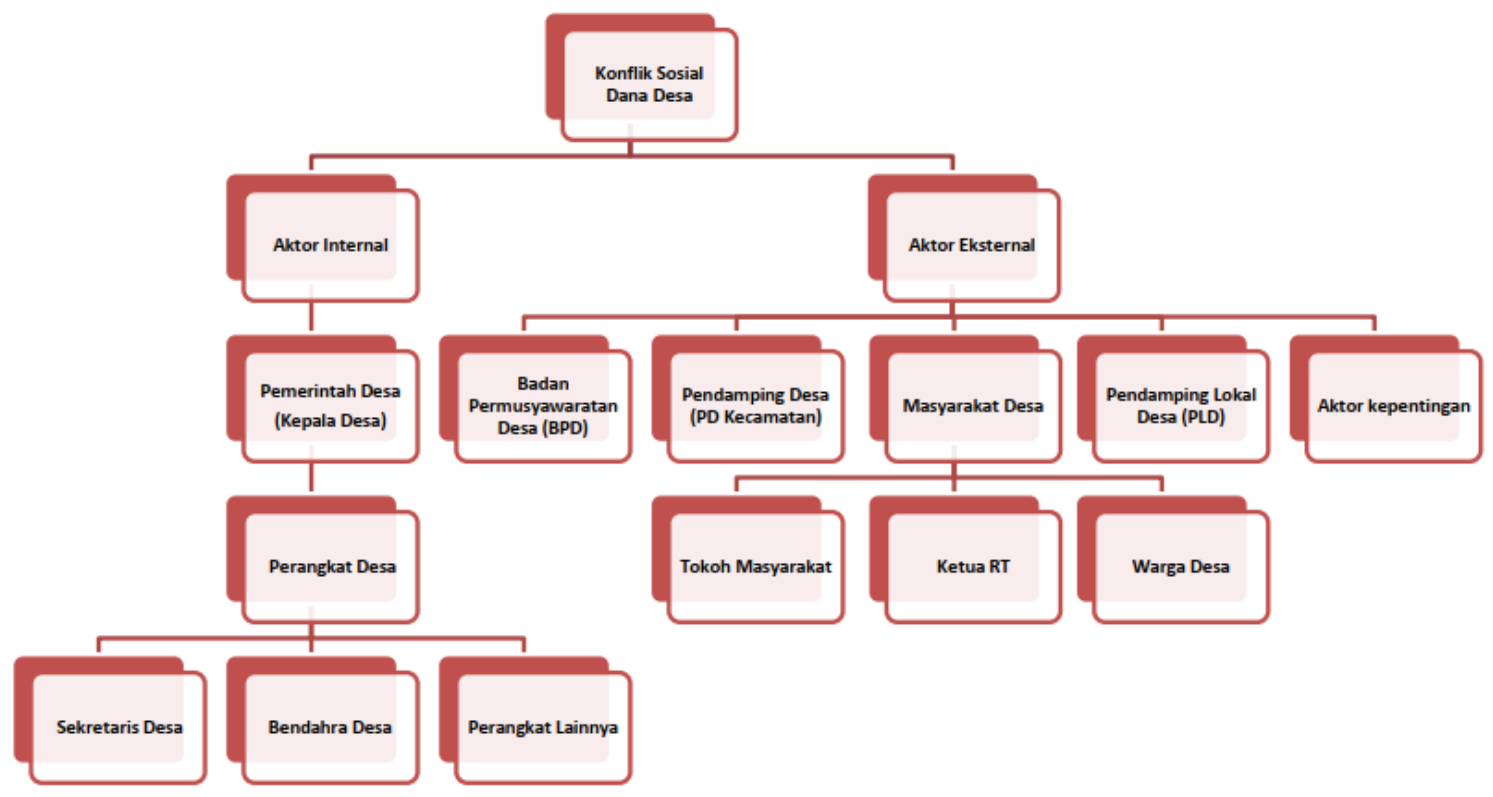

Gambar 4. Peta Aktor dalam Konflik Sosial pengelolaan dana desa

Bentuk-bentuk masing-masing konflik yang terjadi antar aktor baik internal maupun eksternal serta horizotal maupun vertikal dijelaskan pada tabel dibawah ini. Peta tersebut cukup menjelaskan adanya pertentangan kepentingan yang terjadi. Sejalan dengan keinginan atas sumber daya, dan perebutan sumber daya yang terbatas (Barret, 2016). Tabel 3 dibawah menjelaskan peta konflik sosial yang terjadi di Sungai Tabuk. 
Tabel 3. Peta Aktor Konflik Sosial Dana Desa Di Kecamatan Sungai Tabuk Kabupaten Banjar

\begin{tabular}{|c|c|c|c|}
\hline $\begin{array}{l}\text { Aktor konflik } \\
\text { sosial }\end{array}$ & $\begin{array}{l}\text { Internal/ } \\
\text { Eksternal }\end{array}$ & $\begin{array}{l}\text { Bentuk } \\
\text { Konflik } \\
\text { Sosial }\end{array}$ & Konflik Sosial yang Terjadi \\
\hline $\begin{array}{l}\text { Kepala Desa } \\
\text { dengan } \\
\text { Sekretaris } \\
\text { Desa dan } \\
\text { Bendahara } \\
\text { Desa }\end{array}$ & Internal & $\begin{array}{l}\text { Konflik } \\
\text { Vertikal }\end{array}$ & $\begin{array}{l}\text { a. Konflik peran, Sekretaris Desa dan } \\
\text { Bendahara tidak sanggup } \\
\text { menjalankan tugas dan fungsinya, } \\
\text { Kepala Desa mengambil alih fungsi } \\
\text { tersebut } \\
\text { b. Konflik sosial terjadi ketika Kepala } \\
\text { Desa memberhentikan Sekretaris } \\
\text { Desa dan Bendahara secara sepihak }\end{array}$ \\
\hline $\begin{array}{l}\text { Pendamping } \\
\text { Desa (PD) } \\
\text { dengan } \\
\text { Pendamping } \\
\text { Lokal Desa } \\
\text { (PLD) }\end{array}$ & Eks & $\begin{array}{l}\text { Konflik } \\
\text { Vertikal }\end{array}$ & $\begin{array}{l}\text { a. Konflik sosial dari kedua fasilitator ini } \\
\text { terjadi karena adanya kecembruan } \\
\text { PLD kepada PD terkait kesejahteraan } \\
\text { b. Konflik sosial terjadi karena PLD tidak } \\
\text { bisa menjalankan tugas dan fungsinya } \\
\text { karena keterbatasan kemampuan } \\
\text { c. PLD merasa lebih menguasai lapangan } \\
\text { dan keperluan masyarakat desa } \\
\text { daripada PD. }\end{array}$ \\
\hline $\begin{array}{c}\text { Warga Desa } \\
\text { dengan } \\
\text { warga desa }\end{array}$ & Eks & $\begin{array}{c}\text { Konflik } \\
\text { Horizontal }\end{array}$ & $\begin{array}{l}\text { a. Konflik sosial terjadi ketika warga } \\
\text { menjadi pendukung calon-calon } \\
\text { Kepala Desa dalam pemilihan umum } \\
\text { b. Konflik sosial terjadi ketika warga } \\
\text { merasa tidak adil dalam pengerjaan } \\
\text { pembangunan yang seharusnya } \\
\text { dikerjakan secara swadaya }\end{array}$ \\
\hline $\begin{array}{c}\text { Ketua RT } \\
\text { dengan } \\
\text { Ketua RT }\end{array}$ & Eks & $\begin{array}{c}\text { Konflik } \\
\text { Horizontal }\end{array}$ & $\begin{array}{l}\text { a. Pertentangan terjadi diawali dalam } \\
\text { musrenbang atau rapat-rapat } \\
\text { perencanaan pembangunan desa } \\
\text { b. Konflik terjadi karena kecemburuan } \\
\text { pembangunan yang dilakukan tidak } \\
\text { merata }\end{array}$ \\
\hline $\begin{array}{l}\text { Kepala Desa } \\
\text { dengan } \\
\text { Badan } \\
\text { Permusyawar } \\
\text { atan Desa } \\
\text { (BPD) }\end{array}$ & $\begin{array}{l}\text { Internal } \\
\text { dengan } \\
\text { Eksternal }\end{array}$ & $\begin{array}{l}\text { Konflik } \\
\text { Horizontal }\end{array}$ & $\begin{array}{l}\text { a. Konflik sosial ini biasanya dipicu oleh } \\
\text { calon Kepala Desa yang kalah dalam } \\
\text { pemilihan umum akan masuk dalam } \\
\text { BPD } \\
\text { b. Konflik sosial biasanya sulit untuk } \\
\text { dihindari ketika Kepala Desa terpilih } \\
\text { kekuatannya tidak seimbang dengan } \\
\text { BPD }\end{array}$ \\
\hline
\end{tabular}




\begin{tabular}{|c|c|c|c|}
\hline $\begin{array}{l}\text { Kepala Desa } \\
\text { dengan } \\
\text { Pendamping } \\
\text { Desa (PD) }\end{array}$ & $\begin{array}{l}\text { Internal } \\
\text { dengan } \\
\text { Eksternal }\end{array}$ & $\begin{array}{l}\text { Konflik } \\
\text { Vertical }\end{array}$ & $\begin{array}{l}\text { a. Konflik dipicu atau berkaitan dengan } \\
\text { Konflik sosial antara PD dan PLD, PLD } \\
\text { memiliki faktor kedekatan dengan } \\
\text { Kepala Desa, PD sering diminta } \\
\text { Kepala Desa untuk membuat } \\
\text { perencanaan yang matang dan rinci, } \\
\text { dimana seharusnya dikerjakan oleh } \\
\text { PLD }\end{array}$ \\
\hline $\begin{array}{l}\text { Kepala Desa } \\
\text { dengan } \\
\text { Ketua RT dan } \\
\text { Warga Desa }\end{array}$ & $\begin{array}{l}\text { Internal } \\
\text { dengan } \\
\text { Eksternal }\end{array}$ & $\begin{array}{l}\text { Konflik } \\
\text { Vertical }\end{array}$ & $\begin{array}{l}\text { a. Konflik sosial dengan ketua RT } \\
\text { disadari dengan tidak meratanya } \\
\text { pembangunan yang dilakukan Kepala } \\
\text { Desa, faktor ketidakadilan dan Kepala } \\
\text { Desa yang cenderung mendahulukan } \\
\text { wilayah yang memenangkannya } \\
\text { b. Konflik sosial dengan warga desa } \\
\text { sama dengan yang terjadi dengan } \\
\text { Ketua RT, namun ditambah dengan } \\
\text { faktor kecurigaan tentang penggunaan } \\
\text { Dana Desa dan tentang swadaya yang } \\
\text { dirasa tidak berkeadilan. }\end{array}$ \\
\hline
\end{tabular}

\section{Upaya Mitigasi Konflik Sosial Dana Desa di Sungai Tabuk}

Upaya-upaya untuk menghindari potensi konflik terjadi perlu dilakukan, konflik yang sudah terjadi pun perlu untuk diselesaikan dan dijaga agar tidak terjadi konflik yang kembali merugikan dikemudian hari. Konflik sosial dan potensi konflik akibat dampak dari Dana Desa ini terjadi di desa-desa di wilayah Kecamatan Sungai Tabuk Kabupaten Banjar. Teori konflik menyatakan bahwa konflik tidak bisa bisa untuk dihindari (Sumartias \& Rahmat, 2013). Konflik yang tidak bisa dihindari karena merupakan bagian dari kehidupan sosial maka tentunya perlu ada upaya untuk mengatasi agar dampak atau kerugian yang akan diterima dari konflik sosial tersebut dapat diminimalisir sekecil mungkin.

Dana Desa membuat Pemerintahan ditingkat Kecamatan Sungai Tabuk sampai kepada Pemerintah Desa yang berjumlah 20 desa dibawah kecamatan tersebut menjadi dilema. Potensi konflik sosial disadari pemerintah ditempat tersebut ada karena adanya Dana Desa. Potensi konflik sosial jika tidak dikelola dengan baik maka akan berubah menjadi konflik sosial, dan ketika ada konflik maka ada kerugian yang otomatis akan didapat. Kerugian dari konflik sosial dapat diminimalisir dengan melakukan upayaupaya yang berkesinambungan atau saling bersinergi agar hasilnya dapat maksimal. Terlihat pada tabel 4 upaya yang dapat dilakukan. 
Tabel 4. Upaya yang dilakukan untuk Mengatasi Konflik Sosial

\begin{tabular}{|c|c|c|}
\hline Aktor & Tujuan & Upaya \\
\hline $\begin{array}{c}\text { Dinas pemberdayaan } \\
\text { masyarakat dan } \\
\text { Pemerintah Desa } \\
\text { (BPMPD) Kabupaten } \\
\text { Banjar }\end{array}$ & $\begin{array}{l}\text { a. Penyelesaian Konflik } \\
\text { Sosial (sudah terjadi) } \\
\text { b. Penanganan laporan } \\
\text { masyarakat kepada } \\
\text { APH }\end{array}$ & $\begin{array}{l}\text { a. Menjadi mediator dalam konflik } \\
\text { sosial yang terjadi, memfasilitasi } \\
\text { mediasi } \\
\text { b. Menjalin kerjasama dengan } \\
\text { Aparat Penegak Hukum (APH) } \\
\text { dalam pendalaman atas laporan } \\
\text { atau aduan masyarakat }\end{array}$ \\
\hline $\begin{array}{c}\text { Tenaga Ahli (TA) dan } \\
\text { Pendamping Desa } \\
\text { (PD) }\end{array}$ & $\begin{array}{l}\text { Peningkatan kualitas dan } \\
\text { kapasitas Perangkat Desa }\end{array}$ & $\begin{array}{l}\text { Seminar dan forum Tanya jawab yang } \\
\text { dibuka agar harapannya setiap aktor } \\
\text { yang memiliki kewajiban dalam Dana } \\
\text { Desa semakin mengerti tentang tugas } \\
\text { dan fungsinya }\end{array}$ \\
\hline $\begin{array}{l}\text { Aparatur Kecamatan } \\
\text { Sungai Tabuk }\end{array}$ & 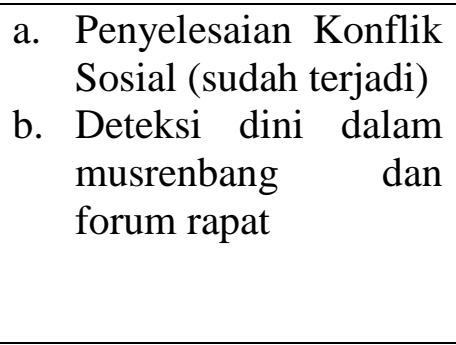 & $\begin{array}{l}\text { a. Menjadi mediator dalam konflik } \\
\text { sosial yang terjadi, memfasilitasi } \\
\text { mediasi } \\
\text { b. Perwakilan dari kecamatan aktif } \\
\text { ikut dalam setiap musrenbang dan } \\
\text { rapat-rapat menentukan arah } \\
\text { pembangunan desa }\end{array}$ \\
\hline $\begin{array}{l}\text { Pendamping Lokal } \\
\text { Desa (PLD) }\end{array}$ & $\begin{array}{c}\text { Meningkatkan } \\
\text { transparansi dan } \\
\text { menurunkan tingkat } \\
\text { kecurigaan masyarakat }\end{array}$ & $\begin{array}{l}\text { Membuka forum rapat pembahasan } \\
\text { proyek dilapangan terbuka, } \\
\text { harapannya agar proyek yang dibahas } \\
\text { dapat disaksikan oleh seluruh } \\
\text { masyarakat desa tanpa terkecuali }\end{array}$ \\
\hline
\end{tabular}

\section{Kesimpulan}

Hasil penelitian menunjukan Peta konflik sosial Dana Desa melibatkan aktor-aktor di pedesaan, aktor tersebut terbagi menjadi dua, aktor internal dan aktor eksternal. Pembagian aktor tersebut berdasarkan pada hak pengelolaan Dana Desa. Aktor Internal merupakan Pemerintahan Desa, dimana terdiri dari Kepala Desa dan Perangkat Desa (Sekretaris Desa dan Bendahara). Aktor eksternal berada diluar Pemerintahan Desa, aktor tersebut adalah Badan Permusyawaratan Desa (BPD), masyarakat Desa, Pendamping Lokal Desa (PLD), dan Pendamping Desa (PD) kecamatan. Konflik sosial terjadi antara aktor internal atau eksternal sendiri, dan juga antar aktor internal dan aktor eksternal.

Potensi konflik sosial Dana Desa juga cenderung dibiarkan dan akan diatasi ketika potensi konflik tersebut sudah berubah menjadi konflik sosial. Upaya-upaya yang dilakukan stakeholder di daerah tidak menyentuh langsung kedalam akar permasalahan yang menimbulkan konflik sosial. Upaya yang dilakukan para stakeholder yang berfokus kepada mediasi ketika konflik sudah terjadi, dan upaya-upaya tersebut belum ada kesinambungan atau belum sinergitas upaya tersebet satu sama lain. Hasil dari upaya yang dilakukan tidak akan maksimal untuk mengatasi konflik sosial di desa-desa diwilayah Kecamatan Sungai Tabuk Kabupaten Banjar. 
Hasil dari penelitian ini adalah upaya untuk mengatasi potensi konflik sosial masih belum maksimal karena tidak mengatasi akar permasalahan dari konflik sosial Dana Desa tersebut. Penelitian ini memberikan saran, saran tersebut akan dibagi menjadi dua saran untuk upaya penanggulangan potensi konflik social yang terjadi dan saran untuk penelitian selanjutnya. Saran untuk upaya mengatasi konflik sosial Dana Desa, yaitu:

a. Upaya yang dilakukan untuk menanggulangi potensi konflik sosial yang terjadi difokuskan kepada mengatasi kesiapan Sumber Daya Manusia (SDM) diperdesaan dengan adanya Dana Desa.

b. Peningkatan kualitas Kepala Desa dan Perangkat Desa (Sekretaris Desa dan Bendahara)

c. Peningkatan kualitas Pendamping Lokal Desa (PLD)

d. Peningkatan tersebut dilakukan dengan cara Seminar Peningkatan Kapasitas yang ditambah dengan praktik atau latihan (workshop/skill training).

e. Sosialisasi kepada masayrakat desa tentang Dana Desa dilakukan secara berkelanjutan

f. Monitoring stakeholder tentang potensi konflik sosial pada saat Musrenbang Desa dan Pemilihan Umum Kepala Desa (upaya preventif)

Saran untuk penelitian selanjutnya tentang Dampak Dana Desa yang melahirkan potensi konflik sosial, yaitu:

a. Peran aktor eksternal yaitu aktor kepentingan dalam konflik sosial Dana Desa lebih didalami dan dilihat peran serta kepentingannya.

b. Pengaruh dinamika politik nasional dalam konflik sosial Dana Desa yang terjadi diwilayah perdesaan

c. Perlunya penelitian kuantitatif yang melihat efektivitas penggunaan Dana Desa ketika tingginya potensi konflik sosial

\section{Daftar Pustaka}

Bahtiar, N. A. (2017). Partisipasi Masyarakat Dalam Pengawasan Program Alokasi Dana Desa (ADD) Di Desa Panjunan Kecamatan Sukodono Kabupaten Sidoarjo. Jurnal Kebijakan dan Manajemen Publik ISSN 2303-341X.

Bakri, H. (2015). Resolusi Konflik melalui Pendekatan Kearifan Lokal Pela Gandong di Kota Ambon. The Politics. 1(1).

Barret, P. S, \& Setiawan, W. (2016). The Built Environment Element of Economic Development in Post Conflict Response in Indonesia. Procedia-Social and Behavioral Science. 234:478-487

[BPS] Badan Pusat Statistika. (2018). Produk Domestik Regional Bruto Provinisi Kalimantan Selatan Menurut Pengeluaran 2014-2018. Banjarbaru: BPS Kalimantan Selatan. 
[BPS] Badan Pusat Statistika. (2018). Statistik Potensi Desa Provinsi Kalimantan Selatan. Banjarbaru: BPS Kalimantan Selatan

Bratakusumah, Supriady D, Riyandi. (2006). Perencanaan Pembangunan Daerah. Jakarta: PT. Gramedia Pustaka Utama.

Creswell, J.W. (2007). Qualitative Inquiry and Research Design. California: Sage Publication.

Czalika, M, \& Kriztina K K. (2009). Civil Conflict and Displacemenet: Village Level Determinants of Forced Migration in Aceh. Journal of Peace Research. 46(3):399418.

Daaraba, H. D. (2017). Pengaruh Program Dana Desa Terhadap Tingkat Partisipasi Masyarakat DI Kecamatan Galesong Utara Kabupaten Takalar. Sosiohumaniora Vol. 19 No. 1

Fisher, S., Abdi D. I., Ludin, J. Williams, \& S. Williams, S. (2000). Working With Conflict: Skill and Strategies for Action. Brimingham: Zed Books

Fahri, L. N. (2017). Pengaruh Pelaksanaan Kebijakan Dana Desa terhadap Manajemen Keuangan Desa dalam Meningkatkan Efektivitas Program Pembangunan Desa. Jurnal Publik ISSN: 1412-7083

Francis, M, \& Tamoya M. (2013). Rural Migration and Land Conflict: Implications on Agricultural Productivity in Uganda. National Graduate Institute for Policy Studies Gripis. GRIPS Discussion Paper 13-17. Diakses tanggal 24 Februari 2019 dari http://www.grips.ac.jp/r-center/wp-content/uploads/13-17.pdf.

Indonesia Corruption Watch. (2018). Outlook Dana Desa 2018 Potensi Penyalahgunaan Anggaran Desa Tahun Politik. Diakses tanggal 24 Februari 2019 dari https://antikorupsi.org/sites/default/files/outlook_desa_2018___icw.pdf

[Kemendes PDTT] Kemeterian Desa, Pembangunan Daerah Tertinggal, dan Transmigrasi Republik Indonesia. (2016). Modul Pelatihan Pratugas Pendamping Desa Implementasi UndangUndang Nomor 6 Tahun 2014 Tentang Desa. Jakarta: Kementerian Desa Pembangunan Daerah Tertinggal dan Transmigrasi Republik Indonesia.

[Kemendagri] Kementerian Dalam Negeri Republik Indonesia. (2016). Peraturan Menteri Dalam Negeri Republik Indonesia Nomor 140 Tahun 2016 tentang Pembentukan Badan Pengelola Perbatasan di Daerah. Jakarta: Kementerian Dalam Negeri Republik Indonesia

(2016). Data Pokok Kemendagri Tahun 2016. Jakarta: Kementerian Dalam Negeri Republik Indonesia.

[Kemenkeu] Kementerian Keuangan. (2017). Buku Saku Dana Desa (Dana Desa untuk Kesejahteraan Rakyat). Jakarta: Kementerian Keuangan Republik Indonesia.

Lewis D, \& Pattinasarany, D. (2009). Determining Citizen Satisfication with Local Public Education in Indonesia: The Significance of Actual Service Growth and Change. 40 (85): 115:121 
Mann, C, and Jeanneaux P. (2009). Two Approaches for Understanding Land-Use Conflict to Improve Rural Planning and Management. Journal of Rural and Community Development (JRCD) ISSN 1712-8277.

Meutia, I., \& Liliana. (2017). Pengelolaan Keuangan Dana Desa. Jurnal Akuntansi Multiparadigma JAMAL ISSN: 2086-7603

Muda, I. (2013). Potensi Konflik Horizontal Di Kota Medan. PERSPEKTIF. ISSN: 20850328 .

Noverman, Y. (2018). Analisis Kesesuain Pengelolaan Dana Desa dengan Peraturan Perundang-Undangan (Studi Kasus di Nagari Bukit Bual Kabupaten Sijunjung. Jurnal Analisis Kebijakan dan Pelaynan Publik. 4(2): 68-81

Pahlevi, I. (2015). Dana Desa dan Permasalahannya. Pusat Pengkajian Pengolahan Data dan Informasi (P3DI) Sekretariat Jenderal DPR RI. Jakarta: Sekretariat Jendral DPR $R I$

Puspaningrum, L. R. (2016). Konflik Politik Dalam Pemlihan Kepala Desa Di Desa Jatimulyo Kecamatan Dlingo Kabupaten Bantul Tahun 2016. Diakses tanggal 24 Februai 2019 dari http://repository.umy.ac.id/ bitstream/handle/123456789/11733/NASKAH\%20PUBLIKASI.pdf?sequence $=11 \&$ isAllowed $=\mathrm{y}$

Reyes-Gracia, V. Orta-Martinez, M. Gueze, M. Luz, A.C. Paneque-Galvez, J. Pino, J. Cristobal, J. (2012). Does Participatory Mapping Increase Conflict? A Randomized Experimental Evalution in The Bolivian Amazon. Diakses tanggal 24 Februai 2019 dari https://heller.brandeis.edu/sustainable-internationaldevelopment/tsimane/wp/TAPS-WP-59.pdf

Roger, J V. (2012). Understanding Propensity to initiate negotiations: An examination of the effects of culture and personality. International Journal of Conflict Management. 23(3):266-289.

Sherif, M., Harvey, O.J., White, B.J., Hood, W.R., Sherif, C.W. (1961). Intergroup Conflict and Cooperation: The Robbers Cave Experiment. Norman: The University Book Exchange.

Shohibuddin, M. (2016). Peluang dan Tantangan Undang-undang dalam Upaya Demokratisasi Tata Kelola Sumber Data Alam Desa: Perspektif Agraria Kritis. Jurnal Sosiologi Masyarakat ISSN: 0852-8489.

Sindonews.com. 2017. Diakses tanggal 20 Agustus 2019. https://nasional.sindonews.com / / read/1260833/18/aspek-prudent-danadesa-dan-potensi-konflik-1511726300

Sinamo, N. (2014). Hukum Tata Negara Indonesia. Jakarta: Permata Aksara.

Sukardi. (2016). Penanganan Konflik Sosial Dengan Pendekatan Keadilan Restoratif. Jurnal Hukum dan Pembangunan ISSN: 0125-9687.

Sumartias, S., \& Rahmat, A. (2013). Faktor-Faktor yang Mempengaruhi Konflik Sosial. UNPAD, 13-20. 
Susan, N. (2013). Scenario building in Law No. 7 of 2012 about social conflict intervention: The Possible future of land conflict mamagement in Indonesia. Procedia Environmental Science. 17:870-879.

Syamsi, I. (2009). Potensi Konflik Sosial Masyarakat di Kelurahan Condongcatur Yogyakarta. Yogyakarta: Laboratorium FSP Universitas Negeri Yogyakarta.

[UU] Undang-Undang Republik Indonesia. (2014). Undang-Undang Nomor 6 Tahun 2014 tentang Desa. Jakarta: Kementerian Hukum dan HAM RI.

Wibisono, N., \& Purnomo, H. (2017). Mengungkap Fenomena Pengawasan Publik Terhadap Dana Desa di Kabupaten Madiun. Jurnal AKSI Vol. 2 ISSN:2528-6145

Wulandari, I., Musyarofah, S., \& Asy'ari, M. A. (2017). Konflik Peran Perangkat Desa Terhadap Pengelolaan Keuangan Desa: Menguak Kesadaran Para Aktor. Jurnal Akutansi ISSN: 2088-768X.

Yamazaki, S, Resosudarmo B, Girsang W, and Hoshino E. (2015). Intra- and InterVillage Conflict in Rural Coastal Communities in Indonesia: The Case of the Kei Islands. University of Tasmania ISBN 978-1-862295-811-1. 